\title{
Complement peptide receptors in GtoPdb v.2021.3
}

\author{
Antonia Cianciulli ${ }^{1}$, Liam Coulthard ${ }^{2}$, Owen Hawksworth ${ }^{2}$, John D. Lee ${ }^{2}$, Xaria X. Li ${ }^{3}$, Vincenzo
} Mitolo $^{1}$, Peter Monk ${ }^{4}$, Maria A. Panaro ${ }^{1}$ and Trent M. Woodruff ${ }^{2}$

1. University of Bari, Italy

2. University of Queensland, Australia

3. The University of Queensland, Australia

4. Sheffield University Medical School, UK

\begin{abstract}
Complement peptide receptors (nomenclature as agreed by the NC-IUPHAR subcommittee on Complement peptide receptors [107]) are activated by the endogenous $\sim 75$ amino-acid anaphylatoxin polypeptides C3a and C5a, generated upon stimulation of the complement cascade. C3a and C5a exert their functions through binding to their receptors (C3aR, C5aR1 and C5aR2), causing cell recruitment and triggering cellular degranulation that contributes to local inflammation.
\end{abstract}

\section{Contents}

This is a citation summary for Complement peptide receptors in the Guide to Pharmacology database (GtoPdb). It exists purely as an adjunct to the database to facilitate the recognition of citations to and from the database by citation analyzers. Readers will almost certainly want to visit the relevant sections of the database which are given here under database links.

GtoPdb is an expert-driven guide to pharmacological targets and the substances that act on them. GtoPdb is a reference work which is most usefully represented as an on-line database. As in any publication this work should be appropriately cited, and the papers it cites should also be recognized. This document provides a citation for the relevant parts of the database, and also provides a reference list for the research cited by those parts. For further details see [26].

Please note that the database version for the citations given in GtoPdb are to the most recent preceding version in which the family or its subfamilies and targets were substantially changed. The links below are to the current version. If you need to consult the cited version, rather than the most recent version, please contact the GtoPdb curators.

\section{Database links}

Complement peptide receptors

https://www.guidetopharmacology.org/GRAC/FamilyDisplayForward?familyId=5

Introduction to Complement peptide receptors

https://www.guidetopharmacology.org/GRAC/FamilyIntroductionForward?familyId=5

Receptors

C3a receptor

https://www.guidetopharmacology.org/GRAC/ObjectDisplayForward?objectId=31

$\mathrm{C}^{5} \mathrm{a}_{1}$ receptor

https://www.guidetopharmacology.org/GRAC/ObjectDisplayForward?objectId=32

$\mathrm{C}^{5} \mathrm{a}_{2}$ receptor

https://www.guidetopharmacology.org/GRAC/ObjectDisplayForward?objectId=33

\section{References}

1. Ager RR, Fonseca MI, Chu SH, Sanderson SD, Taylor SM, Woodruff TM and Tenner AJ. (2010) Microglial C5aR (CD88) expression correlates with amyloid-beta deposition in murine models of Alzheimer's disease. J Neurochem 113: 389-401 [PMID:20132482] 
2. Ahamed J, Haribabu B and Ali H. (2001) Cutting edge: Differential regulation of chemoattractant receptor-induced degranulation and chemokine production by receptor phosphorylation. $J$ Immunol 167: 3559-63 [PMID:11564766]

3. Amara U, Rittirsch D, Flierl M, Bruckner U, Klos A, Gebhard F, Lambris JD and Huber-Lang M. (2008) Interaction between the coagulation and complement system. Adv Exp Med Biol 632: 719 [PMID:19025115]

4. Ames RS, Lee D, Foley JJ, Jurewicz AJ, Tornetta MA, Bautsch W, Settmacher B, Klos A, Erhard $\mathrm{KF}$ and Cousins RD et al.. (2001) Identification of a selective nonpeptide antagonist of the anaphylatoxin C3a receptor that demonstrates antiinflammatory activity in animal models. $J$ Immunol 166: 6341-8 [PMID:11342658]

5. Ames RS, Li Y, Sarau HM, Nuthulaganti P, Foley JJ, Ellis C, Zeng Z, Su K, Jurewicz AJ and Hertzberg RP et al.. (1996) Molecular cloning and characterization of the human anaphylatoxin C3a receptor. J Biol Chem 271: 20231-4 [PMID:8702752]

6. Ames RS, Nuthulaganti P and Kumar C. (1996) In Xenopus oocytes the human C3a and C5a receptors elicit a promiscuous response to the anaphylatoxins. FEBS Lett 395: 157-9 [PMID:8898085]

7. Ames RS, Tornetta MA, Foley JJ, Hugli TE and Sarau HM. (1997) Evidence that the receptor for $\mathrm{C} 4 \mathrm{a}$ is distinct from the C3a receptor. Immunopharmacology 38: 87-92 [PMID:9476119]

8. Arbore G, West EE, Spolski R, Robertson AA, Klos A, Rheinheimer C, Dutow P, Woodruff TM, Yu ZX and O'Neill LA et al.. (2016) T helper 1 immunity requires complement-driven NLRP3 inflammasome activity in CD4+ ${ }^{+}$cells. Science 352: aad1210 [PMID:27313051]

9. Arumugam TV, Shiels IA, Strachan AJ, Abbenante G, Fairlie DP and Taylor SM. (2003) A small molecule C5a receptor antagonist protects kidneys from ischemia/reperfusion injury in rats. Kidney Int 63: 134-42 [PMID:12472776]

10. Arumugam TV, Woodruff TM, Lathia JD, Selvaraj PK, Mattson MP and Taylor SM. (2009) Neuroprotection in stroke by complement inhibition and immunoglobulin therapy. Neuroscience 158: 1074-89 [PMID:18691639]

11. Arumugam TV, Woodruff TM, Stocks SZ, Proctor LM, Pollitt S, Shiels IA, Reid RC, Fairlie DP and Taylor SM. (2004) Protective effect of a human C5a receptor antagonist against hepatic ischaemia-reperfusion injury in rats. J Hepatol 40: 934-41 [PMID:15158333]

12. Astles PC, Brown TJ, Cox P, Halley F, LockeyPM, McCarthy C, McLayIM, Majid TN, Morley AD and Porter B et al.. (1997) New non-peptide C5a receptor antagonists. Bioorg Med Chem Lett 7: 907-912

13. Bamberg CE, Mackay CR, Lee H, Zahra D, Jackson J, Lim YS, Whitfeld PL, Craig S, Corsini E and Lu B et al.. (2010) The C5a receptor (C5aR) C5L2 is a modulator of C5aR-mediated signal transduction. J Biol Chem 285: 7633-44 [PMID:20044484]

14. Banda NK, Hyatt S, Antonioli AH, White JT, Glogowska M, Takahashi K, Merkel TJ, Stahl GL, Mueller-Ortiz S and Wetsel R et al.. (2012) Role of C3a receptors, C5a receptors, and complement protein $\mathrm{C} 6$ deficiency in collagen antibody-induced arthritis in mice. J Immunol 188: 1469-78 [PMID:22205026]

15. Bao L, Osawe I, Haas M and Quigg RJ. (2005) Signaling through up-regulated C3a receptor is key to the development of experimental lupus nephritis. J Immunol 175: 1947-55 [PMID:16034139]

16. Barnes KC, Caraballo L, Muñoz M, Zambelli-Weiner A, Ehrlich E, Burki M, Jimenez S, Mathias RA, Stockton ML and Deindl P et al.. (2004) A novel promoter polymorphism in the gene encoding complement component 5 receptor 1 on chromosome 19q13.3 is not associated with asthma and atopy in three independent populations. Clin Exp Allergy 34: 736-44 [PMID:15144465]

17. Bautsch W, Kretzschmar T, Stühmer T, Kola A, Emde M, Köhl J, Klos A and Bitter-Suermann D. (1992) A recombinant hybrid anaphylatoxin with dual C3a/C5a activity. Biochem J 288 ( Pt 1): 261-6 [PMID:1445269]

18. Beck KD, Nguyen HX, Galvan MD, Salazar DL, Woodruff TM and Anderson AJ. (2010) Quantitative analysis of cellular inflammation after traumatic spinal cord injury: evidence for a multiphasic inflammatory response in the acute to chronic environment. Brain 133: 433-47 [PMID:20085927]

19. Bekker P, Dairaghi D, Seitz L, Leleti M, Wang Y, Ertl L, Baumgart T, Shugarts S, Lohr L and Dang T et al.. (2016) Characterization of Pharmacologic and Pharmacokinetic Properties of CCX168, a Potent and Selective Orally Administered Complement 5a Receptor Inhibitor, Based on Preclinical Evaluation and Randomized Phase 1 Clinical Study. PLoS ONE 11: e0164646 [PMID:27768695]

20. Bellows-Peterson ML, Fung HK, Floudas CA, Kieslich CA, Zhang L, Morikis D, Wareham KJ, Monk PN, Hawksworth OA and Woodruff TM. (2012) De novo peptide design with C3a receptor agonist and antagonist activities: theoretical predictions and experimental validation. $J$ Med Chem 55: 4159-68 [PMID:22500977]

21. Bera MM, Lu B, Martin TR, Cui S, Rhein LM, Gerard C and Gerard NP. (2011) Th17 cytokines are critical for respiratory syncytial virus-associated airway hyperreponsiveness through 
regulation by complement C3a and tachykinins. J Immunol 187: 4245-55 [PMID:21918196]

22. Bergh K, Iversen OJ and Lysvand H. (1993) Surprisingly high levels of anaphylatoxin C5a des Arg are extractable from psoriatic scales. Arch Dermatol Res 285: 131-4 [PMID:8503693]

23. Brennan FH, Jogia T, Gillespie ER, Blomster LV, Li XX, Nowlan B, Williams GM, Jacobson E, Osborne GW and Meunier FA et al.. (2019) Complement receptor C3aR1 controls neutrophil mobilization following spinal cord injury through physiological antagonism of CXCR2. JCI Insight 4: e98254 [PMID:31045582]

24. Brodbeck RM, Cortright DN, Kieltyka AP, Yu J, Baltazar CO, Buck ME, Meade R, Maynard GD, Thurkauf A and Chien DS et al.. (2008) Identification and characterization of NDT 9513727 [N,N-bis(1,3-benzodioxol-5-ylmethyl)-1-butyl-2,4-diphenyl-1H-imidazole-5-methanamine], a novel, orally bioavailable C5a receptor inverse agonist. J Pharmacol Exp Ther 327: 898-909 [PMID:18753409]

25. Buhl AM, Eisfelder BJ, Worthen GS, Johnson GL and Russell M. (1993) Selective coupling of the human anaphylatoxin C5a receptor and alpha 16 in human kidney 293 cells. FEBS Lett 323 : 132-4 [PMID:8388335]

26. Buneman P, Christie G, Davies JA, Dimitrellou R, Harding SD, Pawson AJ, Sharman JL and Wu Y. (2020) Why data citation isn't working, and what to do about it Database 2020 [PMID:32367113]

27. Busch C, Girke G, Kohl B, Stoll C, Lemke M, Krasnici S, Ertel W, Silawal S, John T and SchulzeTanzil G. (2013) Complement gene expression is regulated by pro-inflammatory cytokines and the anaphylatoxin C3a in human tenocytes. Mol Immunol 53: 363-73 [PMID:23070120]

28. Bénard M, Raoult E, Vaudry D, Leprince J, Falluel-Morel A, Gonzalez BJ, Galas L, Vaudry H and Fontaine M. (2008) Role of complement anaphylatoxin receptors (C3aR, C5aR) in the development of the rat cerebellum. Mol Immunol 45: 3767-74 [PMID:18635264]

29. Cain SA and Monk PN. (2002) The orphan receptor C5L2 has high affinity binding sites for complement fragments C5a and C5a des-Arg(74). J Biol Chem 277: 7165-9 [PMID:11773063]

30. Carmona-Fontaine C, Theveneau E, Tzekou A, Tada M, Woods M, Page KM, Parsons M, Lambris JD and Mayor R. (2011) Complement fragment C3a controls mutual cell attraction during collective cell migration. Dev Cell 21: 1026-37 [PMID:22118769]

31. Carvelli J, Demaria O, Vély F, Batista L, Chouaki Benmansour N, Fares J, Carpentier S, Thibult ML, Morel A and Remark R et al.. (2020) Association of COVID-19 inflammation with activation of the C5a-C5aR1 axis. Nature 588: 146-150 [PMID:32726800]

32. Chao TH, Ember JA, Wang M, Bayon Y, Hugli TE and Ye RD. (1999) Role of the second extracellular loop of human $\mathrm{C} 3 \mathrm{a}$ receptor in agonist binding and receptor function. $\mathrm{J}$ Biol Chem 274: 9721-8 [PMID:10092660]

33. Chen NJ, Mirtsos C, Suh D, Lu YC, Lin WJ, McKerlie C, Lee T, Baribault H, Tian H and Yeh WC. (2007) C5L2 is critical for the biological activities of the anaphylatoxins C5a and C3a. Nature 446: 203-7 [PMID:17322907]

34. Chen T, Lennon VA, Liu YU, Bosco DB, Li Y, Yi MH, Zhu J, Wei S and Wu LJ. (2020) Astrocytemicroglia interaction drives evolving neuromyelitis optica lesion. J Clin Invest 130: 4025-4038 [PMID:32568214]

35. Chenoweth DE, Erickson BW and Hugli TE. (1979) Human C5a-related synthetic peptides as neutrophil chemotactic factors. Biochem Biophys Res Commun 86: 227-34 [PMID:426784]

36. Cochrane CG and Müller-Eberhard HJ. (1968) The derivation of two distinct anaphylatoxin activities from the third and fifth components of human complement. J Exp Med 127: 371-86 [PMID:4383923]

37. Coulthard LG and Woodruff TM. (2015) Is the complement activation product C3a a proinflammatory molecule? Re-evaluating the evidence and the myth. J Immunol 194: 3542-8 [PMID:25848071]

38. Crass T, Raffetseder U, Martin U, Grove M, Klos A, Köhl J and Bautsch W. (1996) Expression cloning of the human $\mathrm{C} 3 \mathrm{a}$ anaphylatoxin receptor (C3aR) from differentiated U-937 cells. Eur J Immunol 26: 1944-50 [PMID:8765043]

39. Croker DE, Halai R, Fairlie DP and Cooper MA. (2013) C5a, but not C5a-des Arg, induces upregulation of heteromer formation between complement C5a receptors C5aR and C5L2. Immunol Cell Biol 91: 625-33 [PMID:24060963]

40. Croker DE, Halai R, Kaeslin G, Wende E, Fehlhaber B, Klos A, Monk PN and Cooper MA. (2014) C5a2 can modulate ERK1/2 signaling in macrophages via heteromer formation with C5a1 and $\beta$ arrestin recruitment. Immunol Cell Biol 92: 631-9 [PMID:24777312]

41. Croker DE, Monk PN, Halai R, Kaeslin G, Schofield Z, Wu MC, Clark RJ, Blaskovich MA, Morikis $\mathrm{D}$ and Floudas CA et al.. (2016) Discovery of functionally selective C5aR2 ligands: novel modulators of C5a signalling. Immunol Cell Biol 94: 787-95 [PMID:27108698]

42. Czermak BJ, Sarma V, Pierson CL, Warner RL, Huber-Lang M, Bless NM, Schmal H, Friedl HP and Ward PA. (1999) Protective effects of C5a blockade in sepsis. Nat Med 5: 788-92 [PMID:10395324]

43. Daffern PJ, Pfeifer PH, Ember JA and Hugli TE. (1995) C3a is a chemotaxin for human 
eosinophils but not for neutrophils. I. C3a stimulation of neutrophils is secondary to eosinophil activation. J Exp Med 181: 2119-27 [PMID:7760001]

44. Dantas de Araujo A, Wu C, Wu KC, Reid RC, Durek T, Lim J and Fairlie DP. (2017) EuropiumLabeled Synthetic C3a Protein as a Novel Fluorescent Probe for Human Complement C3a Receptor. Bioconjug Chem 28: 1669-1676 [PMID:28562031]

45. Daveau M, Benard M, Scotte M, Schouft MT, Hiron M, Francois A, Salier JP and Fontaine M. (2004) Expression of a functional C5a receptor in regenerating hepatocytes and its involvement in a proliferative signaling pathway in rat. J Immunol 173: 3418-24 [PMID:15322206]

46. de Haas CJ, Veldkamp KE, Peschel A, Weerkamp F, Van Wamel WJ, Heezius EC, Poppelier MJ, Van Kessel KP and van Strijp JA. (2004) Chemotaxis inhibitory protein of Staphylococcus aureus, a bacterial antiinflammatory agent. J Exp Med 199: 687-95 [PMID:14993252]

47. de Vries B, Köhl J, Leclercq WK, Wolfs TG, van Bijnen AA, Heeringa P and Buurman WA. (2003) Complement factor C5a mediates renal ischemia-reperfusion injury independent from neutrophils. J Immunol 170: 3883-9 [PMID:12646657]

48. Denny KJ, Coulthard LG, Jeanes A, Lisgo S, Simmons DG, Callaway LK, Wlodarczyk B, Finnell RH, Woodruff TM and Taylor SM. (2013) C5a receptor signaling prevents folate deficiencyinduced neural tube defects in mice. J Immunol 190: 3493-9 [PMID:23420882]

49. Denonne F, Binet S, Burton M, Collart P, Defays S, Dipesa A, Eckert M, Giannaras A, Kumar S and Levine B et al.. (2007) Discovery of new C3aR ligands. Part 2: amino-piperidine derivatives. Bioorg Med Chem Lett 17: 3262-5 [PMID:17459702]

50. Deuel TF, Senior RM, Huang JS and Griffin GL. (1982) Chemotaxis of monocytes and neutrophils to platelet-derived growth factor. J Clin Invest 69: 1046-9 [PMID:7076844]

51. Discoverx. G-Protein Coupled Receptor 77 (C5L2).

52. Dunkelberger J, Zhou L, Miwa T and Song WC. (2012) C5aR expression in a novel GFP reporter gene knockin mouse: implications for the mechanism of action of C5aR signaling in T cell immunity. J Immunol 188: 4032-42 [PMID:22430734]

53. Erdei A, Andrásfalvy M, Péterfy H, Tóth G and Pecht I. (2004) Regulation of mast cell activation by complement-derived peptides. Immunol Lett 92: 39-42 [PMID:15081525]

54. Erken E, Gunesacar R and Ozer HT. (2010) Investigation of C5a receptor gene $450 \mathrm{C} / \mathrm{T}$ polymorphism in Turkish patients with familial Mediterranean fever. Mol Biol Rep 37: 273-6 [PMID:19657723]

55. Fayyazi A, Sandau R, Duong LQ, Götze O, Radzun HJ, Schweyer S, Soruri A and Zwirner J. (1999) C5a receptor and interleukin-6 are expressed in tissue macrophages and stimulated keratinocytes but not in pulmonary and intestinal epithelial cells. Am J Pathol 154: 495-501 [PMID:10027407]

56. Fayyazi A, Scheel O, Werfel T, Schweyer S, Oppermann M, Götze O, Radzun HJ and Zwirner J. (2000) The C5a receptor is expressed in normal renal proximal tubular but not in normal pulmonary or hepatic epithelial cells. Immunology 99: 38-45 [PMID:10651939]

57. Ferraiuolo L, Heath PR, Holden H, Kasher P, Kirby J and Shaw PJ. (2007) Microarray analysis of the cellular pathways involved in the adaptation to and progression of motor neuron injury in the SOD1 G93A mouse model of familial ALS. J Neurosci 27: 9201-19 [PMID:17715356]

58. Finch AM, Vogen SM, Sherman SA, Kirnarsky L, Taylor SM and Sanderson SD. (1997) Biologically active conformer of the effector region of human C5a and modulatory effects of $\mathrm{N}$ terminal receptor binding determinants on activity. J Med Chem 40: 877-84 [PMID:9083476]

59. Fischer WH and Hugli TE. (1997) Regulation of B cell functions by C3a and C3a(desArg): suppression of TNF-alpha, IL-6, and the polyclonal immune response. J Immunol 159: 4279-86 [PMID:9379023]

60. Fleming SD, Mastellos D, Karpel-Massler G, Shea-Donohue T, Lambris JD and Tsokos GC. (2003) C5a causes limited, polymorphonuclear cell-independent, mesenteric ischemia/reperfusioninduced injury. Clin Immunol 108: 263-73 [PMID:14499250]

61. Fonseca MI, Ager RR, Chu SH, Yazan O, Sanderson SD, LaFerla FM, Taylor SM, Woodruff TM and Tenner AJ. (2009) Treatment with a C5aR antagonist decreases pathology and enhances behavioral performance in murine models of Alzheimer's disease. J Immunol 183: 1375-83 [PMID:19561098]

62. Francis K, Lewis BM, Monk PN and Ham J. (2008) Complement C5a receptors in the pituitary gland: expression and function. J Endocrinol 199: 417-24 [PMID:19020281]

63. Fukuoka Y and Medof EM. (2001) C5a receptor-mediated production of IL-8 by the human retinal pigment epithelial cell line, ARPE-19. Curr Eye Res 23: 320-5 [PMID:11910520]

64. Füreder W, Agis H, Willheim M, Bankl HC, Maier U, Kishi K, Müller MR, Czerwenka K, Radaszkiewicz T and Butterfield JH et al.. (1995) Differential expression of complement receptors on human basophils and mast cells. Evidence for mast cell heterogeneity and CD88/C5aR expression on skin mast cells. J Immunol 155: 3152-60 [PMID:7673728]

65. Gao H, Neff TA, Guo RF, Speyer CL, Sarma JV, Tomlins S, Man Y, Riedemann NC, Hoesel LM and Younkin E et al.. (2005) Evidence for a functional role of the second C5a receptor C5L2. FASEB J 19: 1003-5 [PMID:15784721] 
66. Gasque P, Singhrao SK, Neal JW, Götze O and Morgan BP. (1997) Expression of the receptor for complement C5a (CD88) is up-regulated on reactive astrocytes, microglia, and endothelial cells in the inflamed human central nervous system. Am J Pathol 150: 31-41 [PMID:9006319]

67. Gasque P, Singhrao SK, Neal JW, Wang P, Sayah S, Fontaine M and Morgan BP. (1998) The receptor for complement anaphylatoxin $\mathrm{C} 3 \mathrm{a}$ is expressed by myeloid cells and nonmyeloid cells in inflamed human central nervous system: analysis in multiple sclerosis and bacterial meningitis. J Immunol 160: 3543-54 [PMID:9531317]

68. Gavrilyuk V, Kalinin S, Hilbush BS, Middlecamp A, McGuire S, Pelligrino D, Weinberg G and Feinstein DL. (2005) Identification of complement 5a-like receptor (C5L2) from astrocytes: characterization of anti-inflammatory properties. J Neurochem 92: 1140-9 [PMID:15715664]

69. Gerard NP, Bao L, Xiao-Ping H, Eddy RL, Shows TB and Gerard C. (1993) Human chemotaxis receptor genes cluster at 19q13.3-13.4. Characterization of the human C5a receptor gene. Biochemistry 32: 1243-50 [PMID:8383526]

70. Gerard NP and Gerard C. (1991) The chemotactic receptor for human C5a anaphylatoxin. Nature 349: 614-7 [PMID:1847994]

71. Gerard NP, Lu B, Liu P, Craig S, Fujiwara Y, Okinaga S and Gerard C. (2005) An antiinflammatory function for the complement anaphylatoxin C5a-binding protein, C5L2. J Biol Chem 280: 39677-80 [PMID:16204243]

72. Girardi G, Berman J, Redecha P, Spruce L, Thurman JM, Kraus D, Hollmann TJ, Casali P, Caroll MC and Wetsel RA et al.. (2003) Complement C5a receptors and neutrophils mediate fetal injury in the antiphospholipid syndrome. J Clin Invest 112: 1644-54 [PMID:14660741]

73. Guo Q, Subramanian H, Gupta K and Ali H. (2011) Regulation of C3a receptor signaling in human mast cells by $\mathrm{G}$ protein coupled receptor kinases. PLoS ONE 6: e22559 [PMID:21799898]

74. Guo RF and Ward PA. (2005) Role of C5a in inflammatory responses. Annu Rev Immunol 23 : 821-52 [PMID:15771587]

75. Halai R, Bellows-Peterson ML, Branchett W, Smadbeck J, Kieslich CA, Croker DE, Cooper MA, Morikis D, Woodruff TM and Floudas CA et al.. (2014) Derivation of ligands for the complement C3a receptor from the C-terminus of C5a. Eur J Pharmacol 745: 176-81 [PMID:25446428]

76. Hannedouche S, Beck V, Leighton-Davies J, Beibel M, Roma G, Oakeley EJ, Lannoy V, Bernard J, Hamon J and Barbieri S et al.. (2013) Identification of the C3a receptor (C3AR1) as the target of the VGF-derived peptide TLQP-21 in rodent cells. J Biol Chem 288: 27434-43 [PMID:23940034]

77. Hartmann K, Henz BM, Krüger-Krasagakes S, Köhl J, Burger R, Guhl S, Haase I, Lippert U and Zuberbier T. (1997) C3a and C5a stimulate chemotaxis of human mast cells. Blood 89: 2863-70 [PMID:9108406]

78. Haviland DL, McCoy RL, Whitehead WT, Akama H, Molmenti EP, Brown A, Haviland JC, Parks WC, Perlmutter DH and Wetsel RA. (1995) Cellular expression of the C5a anaphylatoxin receptor $(\mathrm{C} 5 \mathrm{aR})$ : demonstration of $\mathrm{C} 5 \mathrm{aR}$ on nonmyeloid cells of the liver and lung. J Immunol 154: 1861-9 [PMID:7836770]

79. Hawksworth OA, Li XX, Coulthard LG, Wolvetang EJ and Woodruff TM. (2017) New concepts on the therapeutic control of complement anaphylatoxin receptors. Mol Immunol 89: 36-43 [PMID:28576324]

80. Heimbach L, Li Z, Berkowitz P, Zhao M, Li N, Rubenstein DS, Diaz LA and Liu Z. (2011) The C5a receptor on mast cells is critical for the autoimmune skin-blistering disease bullous pemphigoid. J Biol Chem 286: 15003-9 [PMID:21393236]

81. Helske S, Oksjoki R, Lindstedt KA, Lommi J, Turto H, Werkkala K, Kupari M and Kovanen PT. (2008) Complement system is activated in stenotic aortic valves. Atherosclerosis 196: 190-200 [PMID:17498719]

82. Higginbottom A, Cain SA, Woodruff TM, Proctor LM, Madala PK, Tyndall JD, Taylor SM, Fairlie DP and Monk PN. (2005) Comparative agonist/antagonist responses in mutant human C5a receptors define the ligand binding site. J Biol Chem 280: 17831-17840 [PMID:15661745]

83. Higginbottom A, Wilkinson I, McCullough B, Lanza F, Azorsa DO, Partridge LJ and Monk PN. (2000) Antibody cross-linking of human CD9 and the high-affinity immunoglobulin E receptor stimulates secretion from transfected rat basophilic leukaemia cells. Immunology 99: 546-52 [PMID:10792502]

84. Hollmann TJ, Haviland DL, Kildsgaard J, Watts K and Wetsel RA. (1998) Cloning, expression, sequence determination, and chromosome localization of the mouse complement C3a anaphylatoxin receptor gene. Mol Immunol 35: 137-48 [PMID:9694514]

85. Honczarenko M, Lu B, Nicholson-Weller A, Gerard NP, Silberstein LE and Gerard C. (2005) C5L2 receptor is not involved in C3a / C3a-desArg-mediated enhancement of bone marrow hematopoietic cell migration to CXCL12. Leukemia 19: 1682-3; author reply 1684-5 [PMID:15990859]

86. Hook WA, Siraganian RP and Wahl SM. (1975) Complement-induced histamine release from human basophils. I. Generation of activity in human serum. J Immunol 114: 1185-90 [PMID:46892] 
87. Hu WH, Hu Z, Shen X, Dong LY, Zhou WZ and Yu XX. (2016) C5a receptor enhances hepatocellular carcinoma cell invasiveness via activating ERK1/2-mediated epithelialmesenchymal transition. Exp Mol Pathol 100: 101-8 [PMID:26475622]

88. Huber-Lang M, Sarma JV, Rittirsch D, Schreiber H, Weiss M, Flierl M, Younkin E, Schneider M, Suger-Wiedeck H and Gebhard F et al.. (2005) Changes in the novel orphan, C5a receptor (C5L2), during experimental sepsis and sepsis in humans. J Immunol 174: 1104-10 [PMID:15634936]

89. Huber-Lang MS, Sarma JV, McGuire SR, Lu KT, Guo RF, Padgaonkar VA, Younkin EM, Laudes IJ, Riedemann NC and Younger JG et al.. (2001) Protective effects of anti-C5a peptide antibodies in experimental sepsis. FASEB J 15: 568-70 [PMID:11259369]

90. Huber-Lang MS, Sarma JV, McGuire SR, Lu KT, Padgaonkar VA, Younkin EM, Guo RF, Weber $\mathrm{CH}$, Zuiderweg ER and Zetoune FS et al.. (2003) Structure-function relationships of human C5a and C5aR. J Immunol 170: 6115-24 [PMID:12794141]

91. Huber-Lang MS, Younkin EM, Sarma JV, McGuire SR, Lu KT, Guo RF, Padgaonkar VA, Curnutte JT, Erickson R and Ward PA. (2002) Complement-induced impairment of innate immunity during sepsis. J Immunol 169: 3223-31 [PMID:12218141]

92. Huey R and Hugli TE. (1985) Characterization of a C5a receptor on human polymorphonuclear leukocytes (PMN). J Immunol 135: 2063-8 [PMID:4020139]

93. Humayun S, Gohar M, Volkening K, Moisse K, Leystra-Lantz C, Mepham J, McLean J and Strong MJ. (2009) The complement factor C5a receptor is upregulated in NFL-/- mouse motor neurons. J Neuroimmunol 210: 52-62 [PMID:19286267]

94. Höpken UE, Lu B, Gerard NP and Gerard C. (1996) The C5a chemoattractant receptor mediates mucosal defence to infection. Nature 383: 86-9 [PMID:8779720]

95. Ignatius A, Schoengraf P, Kreja L, Liedert A, Recknagel S, Kandert S, Brenner RE, Schneider M, Lambris JD and Huber-Lang M. (2011) Complement C3a and C5a modulate osteoclast formation and inflammatory response of osteoblasts in synergism with IL-1ß. J Cell Biochem 112: 2594605 [PMID:21598302]

96. Jain U, Woodruff T and Stadnyk A. (2013) The C5a receptor antagonist PMX205 ameliorates experimentally induced colitis associated with increased IL-4 and IL-10. Br J Pharmacol 168: 488-501 [PMID:22924972]

97. Jinsmaa Y, Takenaka Y and Yoshikawa M. (2001) Designing of an orally active complement C3a agonist peptide with anti-analgesic and anti-amnesic activity. Peptides 22: 25-32 [PMID:11179594]

98. Johswich K, Martin M, Bleich A, Kracht M, Dittrich-Breiholz O, Gessner JE, Suerbaum S, Wende E, Rheinheimer C and Klos A. (2009) Role of the C5a receptor (C5aR) in acute and chronic dextran sulfate-induced models of inflammatory bowel disease. Inflamm Bowel Dis 15: 1812-23 [PMID:19714742]

99. Joost P and Methner A. (2002) Phylogenetic analysis of 277 human G-protein-coupled receptors as a tool for the prediction of orphan receptor ligands. Genome Biol 3: RESEARCH0063 [PMID:12429062]

100. Kalant D, Cain SA, Maslowska M, Sniderman AD, Cianflone K and Monk PN. (2003) The chemoattractant receptor-like protein C5L2 binds the C3a des-Arg77/acylation-stimulating protein. J Biol Chem 278: 11123-9 [PMID:12540846]

101. Kalant D, MacLaren R, Cui W, Samanta R, Monk PN, Laporte SA and Cianflone K. (2005) C5L2 is a functional receptor for acylation-stimulating protein. J Biol Chem 280: 23936-44 [PMID:15833747]

102. Kawai M, Quincy DA, Lane B, Mollison KW, Or YS, Luly JR and Carter GW. (1992) Structurefunction studies in a series of carboxyl-terminal octapeptide analogues of anaphylatoxin C5a. $J$ Med Chem 35: 220-223 [PMID:1732540]

103. Kildsgaard J, Hollmann TJ, Matthews KW, Bian K, Murad F and Wetsel RA. (2000) Cutting edge: targeted disruption of the C3a receptor gene demonstrates a novel protective anti-inflammatory role for C3a in endotoxin-shock. J Immunol 165: 5406-9 [PMID:11067891]

104. Kim DY, Martin CB, Lee SN and Martin BK. (2005) Expression of complement protein C5a in a murine mammary cancer model: tumor regression by interference with the cell cycle. Cancer Immunol Immunother 54: 1026-37 [PMID:15868168]

105. Klinker JF, Wenzel-Seifert K and Seifert R. (1996) G-protein-coupled receptors in HL-60 human leukemia cells. Gen Pharmacol 27: 33-54 [PMID:8742493]

106. Klos A, Tenner AJ, Johswich KO, Ager RR, Reis ES and Köhl J. (2009) The role of the anaphylatoxins in health and disease. Mol Immunol 46: 2753-66 [PMID:19477527]

107. Klos A, Wende E, Wareham KJ and Monk PN. (2013) International Union of Pharmacology. LXXXVII. Complement peptide C5a, C4a, and C3a receptors. Pharmacol Rev 65: 500-43 [PMID:23383423]

108. Klos A, Wende E, Wareham KJ and Monk PN. (2013) International Union of Pharmacology. LXXXVII. Complement Peptide C5a, C4a, and C3a Receptors. Pharmacol Rev 65: 500-43 [PMID:23382455] 
109. Konteatis ZD, Siciliano SJ, Van Riper G, Molineaux CJ, Pandya S, Fischer P, Rosen H, Mumford RA and Springer MS. (1994) Development of C5a receptor antagonists. Differential loss of functional responses. J Immunol 153: 4200-5 [PMID:7930622]

110. Kupp LI, Kosco MH, Schenkein HA and Tew JG. (1991) Chemotaxis of germinal center B cells in response to C5a. Eur J Immunol 21: 2697-701 [PMID:1936118]

111. Kwan WH, Hashimoto D, Paz-Artal E, Ostrow K, Greter M, Raedler H, Medof ME, Merad M and Heeger PS. (2012) Antigen-presenting cell-derived complement modulates graft-versus-host disease. J Clin Invest 122: 2234-8 [PMID:22585573]

112. Lajoie S, Lewkowich IP, Suzuki Y, Clark JR, Sproles AA, Dienger K, Budelsky AL and Wills-Karp M. (2010) Complement-mediated regulation of the IL-17A axis is a central genetic determinant of the severity of experimental allergic asthma. Nat Immunol 11: 928-35 [PMID:20802484]

113. Lalli PN, Strainic MG, Yang M, Lin F, Medof ME and Heeger PS. (2008) Locally produced C5a binds to T cell-expressed C5aR to enhance effector T-cell expansion by limiting antigen-induced apoptosis. Blood 112: 1759-66 [PMID:18567839]

114. Laudes IJ, Chu JC, Huber-Lang M, Guo RF, Riedemann NC, Sarma JV, Mahdi F, Murphy HS, Speyer C and Lu KT et al.. (2002) Expression and function of C5a receptor in mouse microvascular endothelial cells. J Immunol 169: 5962-70 [PMID:12421982]

115. Lee CH, Katz A and Simon MI. (1995) Multiple regions of G alpha 16 contribute to the specificity of activation by the C5a receptor. Mol Pharmacol 47: 218-223 [PMID:7870028]

116. Lee DK, George SR, Cheng R, Nguyen T, Liu Y, Brown M, Lynch KR and O'Dowd BF. (2001) Identification of four novel human $\mathrm{G}$ protein-coupled receptors expressed in the brain. Brain Res Mol Brain Res 86: 13-22 [PMID:11165367]

117. Lee H, Zahra D, Vogelzang A, Newton R, Thatcher J, Quan A, So T, Zwirner J, Koentgen F and Padkjaer SB et al.. (2006) Human C5aR knock-in mice facilitate the production and assessment of anti-inflammatory monoclonal antibodies. Nat Biotechnol 24: 1279-84 [PMID:16980974]

118. Lee JD, Kumar V, Fung JNT, Ruitenberg MJ, Noakes PG and Woodruff TM. (2017) Pharmacological inhibition of complement C5a-C5a 1 receptor signalling ameliorates disease pathology in the hSOD1 G93A mouse model of amyotrophic lateral sclerosis Br J Pharmacol 174: 689-699 [PMID:28128456]

119. Lewis AG, Köhl G, Ma Q, Devarajan P and Köhl J. (2008) Pharmacological targeting of C5a receptors during organ preservation improves kidney graft survival. Clin Exp Immunol 153: 117-26 [PMID:18505432]

120. Li R, Coulthard LG, Wu MC, Taylor SM and Woodruff TM. (2013) C5L2: a controversial receptor of complement anaphylatoxin, C5a. FASEB J 27: 855-64 [PMID:23239822]

121. Li XX, Clark RJ and Woodruff TM. (2020) C5aR2 Activation Broadly Modulates the Signaling and Function of Primary Human Macrophages. J Immunol 205: 1102-1112 [PMID:32611725]

122. Li XX, Kumar V, Clark RJ, Lee JD and Woodruff TM. (2020) The "C3aR Antagonist" SB290157 is a Partial C5aR2 Agonist. Front Pharmacol 11: 591398 [PMID:33551801]

123. Li XX, Lee JD, Kemper C and Woodruff TM. (2019) The Complement Receptor C5aR2: A Powerful Modulator of Innate and Adaptive Immunity. J Immunol 202: 3339-3348 [PMID:31160390]

124. Li XX, Lee JD, Massey NL, Guan C, Robertson AAB, Clark RJ and Woodruff TM. (2020) Pharmacological characterisation of small molecule C5aR1 inhibitors in human cells reveals biased activities for signalling and function. Biochem Pharmacol 180: 114156 [PMID:32682759]

125. Lienenklaus S, Ames RS, Tornetta MA, Sarau HM, Foley JJ, Crass T, Sohns B, Raffetseder U, Grove M and Hölzer A et al.. (1998) Human anaphylatoxin C4a is a potent agonist of the guinea pig but not the human C3a receptor. J Immunol 161: 2089-93 [PMID:9725198]

126. Lillegard KE, Loeks-Johnson AC, Opacich JW, Peterson JM, Bauer AJ, Elmquist BJ, Regal RR, Gilbert JS and Regal JF. (2014) Differential effects of complement activation products c3a and c5a on cardiovascular function in hypertensive pregnant rats. J Pharmacol Exp Ther 351: 34451 [PMID:25150279]

127. Lim R and Lappas M. (2012) Decreased expression of complement 3a receptor (C3aR) in human placentas from severe preeclamptic pregnancies. Eur J Obstet Gynecol Reprod Biol 165: 194-8 [PMID:22901903]

128. Maeda Y, Kawano Y, Wada Y, Yatsuda J, Motoshima T, Murakami Y, Kikuchi K, Imamura T and Eto M. (2015) C5aR is frequently expressed in metastatic renal cell carcinoma and plays a crucial role in cell invasion via the ERK and PI3 kinase pathways. Oncol Rep 33: 1844-50 [PMID:25682807]

129. March DR, Proctor LM, Stoermer MJ, Sbaglia R, Abbenante G, Reid RC, Woodruff TM, Wadi K, Paczkowski N and Tyndall JD et al.. (2004) Potent cyclic antagonists of the complement C5a receptor on human polymorphonuclear leukocytes. Relationships between structures and activity. Mol Pharmacol 65: 868-79 [PMID:15044616]

130. Marcil M, Vu H, Cui W, Dastani Z, Engert JC, Gaudet D, Castro-Cabezas M, Sniderman AD, Genest J and Cianflone K. (2006) Identification of a novel C5L2 variant (S323I) in a French Canadian family with familial combined hyperlipemia. Arterioscler Thromb Vasc Biol 26: 1619- 
25 [PMID:16627811]

131. Martin BK. (2007) Transcriptional control of complement receptor gene expression. Immunol Res 39: 146-59 [PMID:17917062]

132. Mathieu MC, Sawyer N, Greig GM, Hamel M, Kargman S, Ducharme Y, Lau CK, Friesen RW, O'Neill GP and Gervais FG et al.. (2005) The C3a receptor antagonist SB 290157 has agonist activity. Immunol Lett 100: 139-45 [PMID:16154494]

133. Miyabe Y, Miyabe C, Mani V, Mempel TR and Luster AD. (2019) Atypical complement receptor C5aR2 transports C5a to initiate neutrophil adhesion and inflammation. Sci Immunol 4 [PMID:31076525]

134. Monk PN, Barker MD, Partridge LJ and Pease JE. (1995) Mutation of glutamate 199 of the human $\mathrm{C} 5$ a receptor defines a binding site for ligand distinct from the receptor $\mathrm{N}$ terminus. $J$ Biol Chem 270: 16625-9 [PMID:7622471]

135. Monk PN, Pease JE and Barker MD. (1994) C5a stimulus-secretion coupling in rat basophilic leukaemia (RBL-2H3) cells transfected with the human C5a receptor is mediated by pertussis and cholera toxin-sensitive G proteins. Biochem Mol Biol Int 32: 13-20 [PMID:8012277]

136. Monk PN, Scola AM, Madala P and Fairlie DP. (2007) Function, structure and therapeutic potential of complement C5a receptors. Br J Pharmacol 152: 429-48 [PMID:17603557]

137. Monsinjon T, Gasque P, Chan P, Ischenko A, Brady JJ and Fontaine MC. (2003) Regulation by complement $\mathrm{C} 3 \mathrm{a}$ and $\mathrm{C} 5 \mathrm{a}$ anaphylatoxins of cytokine production in human umbilical vein endothelial cells. FASEB J 17: 1003-14 [PMID:12773483]

138. Moriconi A, Cunha TM, Souza GR, Lopes AH, Cunha FQ, Carneiro VL, Pinto LG, Brandolini L, Aramini A and Bizzarri C et al.. (2014) Targeting the minor pocket of C5aR for the rational design of an oral allosteric inhibitor for inflammatory and neuropathic pain relief. Proc Natl Acad Sci USA 111: 16937-42 [PMID:25385614]

139. Mrowietz U, Koch WA, Zhu K, Wiedow O, Bartels J, Christophers E and Schröder JM. (2001) Psoriasis scales contain C5a as the predominant chemotaxin for monocyte-derived dendritic cells. Exp Dermatol 10: 238-45 [PMID:11493312]

140. Nabizadeh JA, Manthey HD, Steyn FJ, Chen W, Widiapradja A, Md Akhir FN, Boyle GM, Taylor SM, Woodruff TM and Rolfe BE. (2016) The Complement C3a Receptor Contributes to Melanoma Tumorigenesis by Inhibiting Neutrophil and CD4+ T Cell Responses. J Immunol 196: 4783-92 [PMID:27183625]

141. Nataf S, Davoust N, Ames RS and Barnum SR. (1999) Human T cells express the C5a receptor and are chemoattracted to C5a. J Immunol 162: 4018-23 [PMID:10201923]

142. Nataf S, Levison SW and Barnum SR. (2001) Expression of the anaphylatoxin C5a receptor in the oligodendrocyte lineage. Brain Res 894: 321-6 [PMID:11251209]

143. Niebuhr M, Bäumer W, Kietzmann M, Wichmann K, Heratizadeh A and Werfel T. (2012) Participation of complement 3a receptor (C3aR) in the sensitization phase of Th2 mediated allergic contact dermatitis. Exp Dermatol 21: 52-6 [PMID:22151392]

144. Nishiura H, Shibuya Y and Yamamoto T. (1998) S19 ribosomal protein cross-linked dimer causes monocyte-predominant infiltration by means of molecular mimicry to complement C5a. Lab Invest 78: 1615-23 [PMID:9881961]

145. Nishiura H, Zhao R and Yamamoto T. (2011) The role of the ribosomal protein S19 C-terminus in altering the chemotaxis of leucocytes by causing functional differences in the C5a receptor response. J Biochem 150: 271-7 [PMID:21613290]

146. Nitta H, Murakami Y, Wada Y, Eto M, Baba H and Imamura T. (2014) Cancer cells release anaphylatoxin C5a from C5 by serine protease to enhance invasiveness. Oncol Rep 32: 1715-9 [PMID:25050844]

147. Nitta H, Wada Y, Kawano Y, Murakami Y, Irie A, Taniguchi K, Kikuchi K, Yamada G, Suzuki K and Honda J et al.. (2013) Enhancement of human cancer cell motility and invasiveness by anaphylatoxin C5a via aberrantly expressed C5a receptor (CD88). Clin Cancer Res 19: 2004-13 [PMID:23287562]

148. O'Barr SA, Caguioa J, Gruol D, Perkins G, Ember JA, Hugli T and Cooper NR. (2001) Neuronal expression of a functional receptor for the C5a complement activation fragment. J Immunol 166: 4154-62 [PMID:11238666]

149. Ohno M, Hirata T, Enomoto M, Araki T, Ishimaru H and Takahashi TA. (2000) A putative chemoattractant receptor, C5L2, is expressed in granulocyte and immature dendritic cells, but not in mature dendritic cells. Mol Immunol 37: 407-12 [PMID:11090875]

150. Okinaga S, Slattery D, Humbles A, Zsengeller Z, Morteau O, Kinrade MB, Brodbeck RM, Krause JE, Choe HR and Gerard NP et al.. (2003) C5L2, a nonsignaling C5A binding protein. Biochemistry 42: 9406-15 [PMID:12899627]

151. Onuma H, Masuko-Hongo K, Yuan G, Sakata M, Nakamura H, Kato T, Aoki H and Nishioka K. (2002) Expression of the anaphylatoxin receptor C5aR (CD88) by human articular chondrocytes. Rheumatol Int 22: 52-5 [PMID:12070675]

152. Oskeritzian CA, Zhao W, Min HK, Xia HZ, Pozez A, Kiev J and Schwartz LB. (2005) Surface CD88 functionally distinguishes the MCTC from the MCT type of human lung mast cell. J Allergy 
Clin Immunol 115: 1162-8 [PMID:15940129]

153. Otto M, Hawlisch H, Monk PN, Müller M, Klos A, Karp CL and Köhl J. (2004) C5a mutants are potent antagonists of the C5a receptor (CD88) and of C5L2: position 69 is the locus that determines agonism or antagonism. J Biol Chem 279: 142-51 [PMID:14570896]

154. Paczkowski NJ, Finch AM, Whitmore JB, Short AJ, Wong AK, Monk PN, Cain SA, Fairlie DP and Taylor SM. (1999) Pharmacological characterization of antagonists of the C5a receptor. $\mathrm{BrJ}$ Pharmacol 128: 1461-6 [PMID:10602324]

155. Paglialunga S, Schrauwen P, Roy C, Moonen-Kornips E, Lu H, Hesselink MK, Deshaies Y, Richard D and Cianflone K. (2007) Reduced adipose tissue triglyceride synthesis and increased muscle fatty acid oxidation in C5L2 knockout mice. J Endocrinol 194: 293-304 [PMID:17641279]

156. Pandey S, Li XX, Srivastava A, Baidya M, Kumari P, Dwivedi H, Chaturvedi M, Ghosh E, Woodruff TM and Shukla AK. (2019) Partial ligand-receptor engagement yields functional bias at the human complement receptor, C5aR1. J Biol Chem 294: 9416-9429 [PMID:31036565]

157. Pandey S, Maharana J, Li XX, Woodruff TM and Shukla AK. (2020) Emerging Insights into the Structure and Function of Complement C5a Receptors. Trends Biochem Sci 45: 693-705 [PMID:32402749]

158. Pasupuleti M, Walse B, Svensson B, Malmsten M and Schmidtchen A. (2008) Rational design of antimicrobial C3a analogues with enhanced effects against Staphylococci using an integrated structure and function-based approach. Biochemistry 47: 9057-70 [PMID:18690701]

159. Pavlovski D, Thundyil J, Monk PN, Wetsel RA, Taylor SM and Woodruff TM. (2012) Generation of complement component C5a by ischemic neurons promotes neuronal apoptosis. FASEB J 26: 3680-90 [PMID:22651932]

160. Peng Q, Li K, Anderson K, Farrar CA, Lu B, Smith RA, Sacks SH and Zhou W. (2008) Local production and activation of complement up-regulates the allostimulatory function of dendritic cells through C3a-C3aR interaction. Blood 111: 2452-61 [PMID:18056835]

161. Peng Q, Li K, Sacks SH and Zhou W. (2009) The role of anaphylatoxins C3a and C5a in regulating innate and adaptive immune responses. Inflamm Allergy Drug Targets 8: 236-46 [PMID:19601884]

162. Postma B, Poppelier MJ, van Galen JC, Prossnitz ER, van Strijp JA, de Haas CJ and van Kessel KP. (2004) Chemotaxis inhibitory protein of Staphylococcus aureus binds specifically to the C5a and formylated peptide receptor. J Immunol 172: 6994-7001 [PMID:15153520]

163. Poursharifi P, Lapointe M, Pétrin D, Devost D, Gauvreau D, Hébert TE and Cianflone K. (2013) C5L2 and C5aR interaction in adipocytes and macrophages: insights into adipoimmunology. Cell Signal 25: 910-8 [PMID:23268185]

164. Proctor LM, Woodruff TM, Sharma P, Shiels IA and Taylor SM. (2006) Transdermal pharmacology of small molecule cyclic C5a antagonists. Adv Exp Med Biol 586: 329-45 [PMID:16893082]

165. Purwar R, Wittmann M, Zwirner J, Oppermann M, Kracht M, Dittrich-Breiholz O, Gutzmer R and Werfel T. (2006) Induction of C3 and CCL2 by C3a in keratinocytes: a novel autocrine amplification loop of inflammatory skin reactions. J Immunol 177: 4444-50 [PMID:16982879]

166. Quell KM, Karsten CM, Kordowski A, Almeida LN, Briukhovetska D, Wiese AV, Sun J, Ender F, Antoniou K and Schröder T et al.. (2017) Monitoring C3aR Expression Using a Floxed tdTomatoC3aR Reporter Knock-in Mouse. J Immunol 199: 688-706 [PMID:28626064]

167. Raby AC, Holst B, Davies J, Colmont C, Laumonnier Y, Coles B, Shah S, Hall J, Topley N and Köhl J et al.. (2011) TLR activation enhances C5a-induced pro-inflammatory responses by negatively modulating the second C5a receptor, C5L2. Eur J Immunol 41: 2741-52 [PMID:21630250]

168. Rahpeymai Y, Hietala MA, Wilhelmsson U, Fotheringham A, Davies I, Nilsson AK, Zwirner J, Wetsel RA, Gerard C and Pekny M et al.. (2006) Complement: a novel factor in basal and ischemia-induced neurogenesis. EMBO J 25: 1364-74 [PMID:16498410]

169. Reid RC, Yau MK, Singh R, Hamidon JK, Lim J, Stoermer MJ and Fairlie DP. (2014) Potent heterocyclic ligands for human complement c3a receptor. J Med Chem 57: 8459-70 [PMID:25259874]

170. Reid RC, Yau MK, Singh R, Hamidon JK, Reed AN, Chu P, Suen JY, Stoermer MJ, Blakeney JS and Lim J et al.. (2013) Downsizing a human inflammatory protein to a small molecule with equal potency and functionality. Nat Commun 4: 2802 [PMID:24257095]

171. Reis ES, Chen H, Sfyroera G, Monk PN, Köhl J, Ricklin D and Lambris JD. (2012) C5a receptordependent cell activation by physiological concentrations of desarginated C5a: insights from a novel label-free cellular assay. J Immunol 189: 4797-805 [PMID:23041570]

172. Riedemann NC, Guo RF, Hollmann TJ, Gao H, Neff TA, Reuben JS, Speyer CL, Sarma JV, Wetsel RA and Zetoune FS et al.. (2004) Regulatory role of C5a in LPS-induced IL-6 production by neutrophils during sepsis. FASEB J 18: 370-2 [PMID:14688199]

173. Rittirsch D, Flierl MA, Nadeau BA, Day DE, Huber-Lang M, Mackay CR, Zetoune FS, Gerard NP, Cianflone K and Köhl J et al.. (2008) Functional roles for C5a receptors in sepsis. Nat Med 14: 551-7 [PMID:18454156] 
174. Robertson N, Rappas M, Doré AS, Brown J, Bottegoni G, Koglin M, Cansfield J, Jazayeri A, Cooke RM and Marshall FH. (2018) Structure of the complement C5a receptor bound to the extrahelical antagonist NDT9513727. Nature 553: 111-114 [PMID:29300009]

175. Rowley JA, Reid RC, Poon EKY, Wu KC, Lim J, Lohman RJ, Hamidon JK, Yau MK, Halili MA and Durek T et al.. (2020) Potent Thiophene Antagonists of Human Complement C3a Receptor with Anti-Inflammatory Activity. J Med Chem 63: 529-541 [PMID:31910011]

176. Sayah S, Jauneau AC, Patte C, Tonon MC, Vaudry H and Fontaine M. (2003) Two different transduction pathways are activated by C3a and C5a anaphylatoxins on astrocytes. Brain Res Mol Brain Res 112: 53-60 [PMID:12670702]

177. Schnatbaum K, Locardi E, Scharn D, Richter U, Hawlisch H, Knolle J and Polakowski T. (2006) Peptidomimetic C5a receptor antagonists with hydrophobic substitutions at the C-terminus: increased receptor specificity and in vivo activity. Bioorg Med Chem Lett 16: 5088-92 [PMID:16876401]

178. Schraufstatter IU, Discipio RG, Zhao M and Khaldoyanidi SK. (2009) C3a and C5a are chemotactic factors for human mesenchymal stem cells, which cause prolonged ERK1/2 phosphorylation. J Immunol 182: 3827-36 [PMID:19265162]

179. Schraufstatter IU, Trieu K, Sikora L, Sriramarao P and DiScipio R. (2002) Complement c3a and c5a induce different signal transduction cascades in endothelial cells. J Immunol 169: 2102-10 [PMID:12165538]

180. Scola AM, Higginbottom A, Partridge LJ, Reid RC, Woodruff T, Taylor SM, Fairlie DP and Monk PN. (2007) The role of the N-terminal domain of the complement fragment receptor C5L2 in ligand binding. J Biol Chem 282: 3664-71 [PMID:17158873]

181. Scola AM, Johswich KO, Morgan BP, Klos A and Monk PN. (2009) The human complement fragment receptor, C5L2, is a recycling decoy receptor. Mol Immunol 46: 1149-62 [PMID:19100624]

182. Scully CC, Blakeney JS, Singh R, Hoang HN, Abbenante G, Reid RC and Fairlie DP. (2010) Selective hexapeptide agonists and antagonists for human complement C3a receptor. J Med Chem 53: 4938-48 [PMID:20527893]

183. Sewell DL, Nacewicz B, Liu F, Macvilay S, Erdei A, Lambris JD, Sandor M and Fabry Z. (2004) Complement C3 and C5 play critical roles in traumatic brain cryoinjury: blocking effects on neutrophil extravasation by C5a receptor antagonist. J Neuroimmunol 155: 55-63 [PMID:15342196]

184. Shinjyo N, Ståhlberg A, Dragunow M, Pekny M and Pekna M. (2009) Complement-derived anaphylatoxin C3a regulates in vitro differentiation and migration of neural progenitor cells. Stem Cells 27: 2824-32 [PMID:19785034]

185. Short A, Wong AK, Finch AM, Haaima G, Shiels IA, Fairlie DP and Taylor SM. (1999) Effects of a new C5a receptor antagonist on C5a- and endotoxin-induced neutropenia in the rat. $B r J$ Pharmacol 126: 551-4 [PMID:10188960]

186. Short AJ, Paczkowski NJ, Vogen SM, Sanderson SD and Taylor SM. (1999) Response-selective C5a agonists: differential effects on neutropenia and hypotension in the rat. BrJ Pharmacol 128: 511-4 [PMID:10516626]

187. Siciliano SJ, Rollins TE, DeMartino J, Konteatis Z, Malkowitz L, Van Riper G, Bondy S, Rosen H and Springer MS. (1994) Two-site binding of C5a by its receptor: an alternative binding paradigm for G protein-coupled receptors. Proc Natl Acad Sci USA 91: 1214-8 [PMID:8108389]

188. Siciliano SJ, Rollins TE and Springer MS. (1990) Interaction between the C5a receptor and Gi in both the membrane-bound and detergent-solubilized states. J Biol Chem 265: 19568-74 [PMID:2123189]

189. Soruri A, Kim S, Kiafard Z and Zwirner J. (2003) Characterization of C5aR expression on murine myeloid and lymphoid cells by the use of a novel monoclonal antibody. Immunol Lett 88: 47-52 [PMID:12853161]

190. Strainic MG, Liu J, Huang D, An F, Lalli PN, Muqim N, Shapiro VS, Dubyak GR, Heeger PS and Medof ME. (2008) Locally produced complement fragments C5a and C3a provide both costimulatory and survival signals to naive CD4+ T cells. Immunity 28: 425-35 [PMID:18328742]

191. Sumichika H, Sakata K, Sato N, Takeshita S, Ishibuchi S, Nakamura M, Kamahori T, Ehara S, Itoh $\mathrm{K}$ and Ohtsuka $\mathrm{T}$ et al.. (2002) Identification of a potent and orally active non-peptide C5a receptor antagonist. J Biol Chem 277: 49403-7 [PMID:12384495]

192. Sun L, Gao H, Sarma VJ, Guo RF and Ward PA. (2006) Adenovirus-mediated in vivo silencing of anaphylatoxin receptor C5aR. J Biomed Biotechnol 2006: 28945 [PMID:17057363]

193. Suvorova ES, Gripentrog JM, Oppermann M and Miettinen HM. (2008) Role of the carboxyl terminal di-leucine in phosphorylation and internalization of C5a receptor. Biochim Biophys Acta 1783: 1261-70 [PMID:18346468]

194. Sünderhauf A, Skibbe K, Preisker S, Ebbert K, Verschoor A, Karsten CM, Kemper C, Huber-Lang M, Basic M and Bleich A et al.. (2017) Regulation of epithelial cell expressed C3 in the intestine - Relevance for the pathophysiology of inflammatory bowel disease? Mol Immunol 90: 227-238 
[PMID:28843904]

195. Takafuji S, Tadokoro K, Ito K and Dahinden CA. (1994) Degranulation from human eosinophils stimulated with C3a and C5a. Int Arch Allergy Immunol 104 Suppl 1: 27-9 [PMID:8156000]

196. Takahashi M, Moriguchi S, Suganuma H, Shiota A, Tani F, Usui H, Kurahashi K, Sasaki R and Yoshikawa M. (1997) Identification of casoxin C, an ileum-contracting peptide derived from bovine kappa-casein, as an agonist for C3a receptors. Peptides 18: 329-36 [PMID:9145417]

197. Takahashi M, Moriguchi S, Yoshikawa M and Sasaki R. (1994) Isolation and characterization of oryzatensin: a novel bioactive peptide with ileum-contracting and immunomodulating activities derived from rice albumin. Biochem Mol Biol Int 33: 1151-8 [PMID:7804141]

198. Takahashi M, Moriguti S, Minami T, Suganuma H, Shiota A, Takenaka Y, Tani F, Sasaki R and Yoshikawa M. (1998) Albutensin A, an ileum-contracting peptide derived from serum albumin, acts through both receptors for complement C3a, and C5a Peptide Science 4: 1.7

199. Tamamis P, Kieslich CA, Nikiforovich GV, Woodruff TM, Morikis D and Archontis G. (2014) Insights into the mechanism of C5aR inhibition by PMX53 via implicit solvent molecular dynamics simulations and docking. BMC Biophys 7: 5 [PMID:25170421]

200. Tardif M, Brouchon L, Rabiet MJ and Boulay F. (2003) Direct binding of a fragment of the Wiskott-Aldrich syndrome protein to the C-terminal end of the anaphylatoxin C5a receptor. Biochem J 372: 453-63 [PMID:12600272]

201. Ten RM, Carmona EM, Babovic-Vuksanovic D and Katzmann JA. (1999) Mannose-binding lectin deficiency associated with neutrophil chemotactic unresponsiveness to C5a. J Allergy Clin Immunol 104: 419-24 [PMID:10452765]

202. Tokodai K, Goto M, Inagaki A, Imura T, Nakanishi W and Satomi S. (2011) Expression of receptors for anaphylatoxins C3a and C5a on rat islet preparations. Transplant Proc 43: $3179-80$ [PMID:22099750]

203. Tsuji RF, Yamakoshi J, Uramoto M, Koshino H, Saito M, Kikuchi M and Masuda T. (1995) Antiinflammatory effects and specificity of L-156,602: comparison of effects on concanavalin A and zymosan-induced footpad edema, and contact sensitivity response. Immunopharmacology 29: 79-87 [PMID:7768675]

204. Unnewehr H, Rittirsch D, Sarma JV, Zetoune F, Flierl MA, Perl M, Denk S, Weiss M, Schneider ME and Monk PN et al.. (2013) Changes and regulation of the C5a receptor on neutrophils during septic shock in humans. J Immunol 190: 4215-25 [PMID:23479227]

205. Van Beek J, Bernaudin M, Petit E, Gasque P, Nouvelot A, MacKenzie ET and Fontaine M. (2000) Expression of receptors for complement anaphylatoxins C3a and C5a following permanent focal cerebral ischemia in the mouse. Exp Neurol 161: 373-82 [PMID:10683302]

206. Van Lith LH, Oosterom J, Van Elsas A and Zaman GJ. (2009) C5a-stimulated recruitment of betaarrestin2 to the nonsignaling 7-transmembrane decoy receptor C5L2. J Biomol Screen 14: 106775 [PMID:19641221]

207. van Werkhoven MB, Damman J, Daha MR, Krikke C, van Goor H, van Son WJ, Hillebrands JL, van Dijk MC and Seelen MA. (2013) Novel insights in localization and expression levels of C5aR and C5L2 under native and post-transplant conditions in the kidney. Mol Immunol 53: 237-45 [PMID:22960554]

208. Venkatesha RT, Berla Thangam E, Zaidi AK and Ali H. (2005) Distinct regulation of C3a-induced MCP-1/CCL2 and RANTES/CCL5 production in human mast cells by extracellular signal regulated kinase and PI3 kinase. Mol Immunol 42: 581-7 [PMID:15607817]

209. Vergunst CE, Gerlag DM, Dinant H, Schulz L, Vinkenoog M, Smeets TJ, Sanders ME, Reedquist KA and Tak PP. (2007) Blocking the receptor for C5a in patients with rheumatoid arthritis does not reduce synovial inflammation. Rheumatology (Oxford) 46: 1773-8 [PMID:17965442]

210. Vibhuti A, Gupta K, Subramanian H, Guo Q and Ali H. (2011) Distinct and shared roles of $\beta$ arrestin-1 and $\beta$-arrestin-2 on the regulation of $C 3$ a receptor signaling in human mast cells. PLOS ONE 6: e19585 [PMID:21589858]

211. Vlaar APJ, de Bruin S, Busch M, Timmermans SAMEG, van Zeggeren IE, Koning R, Ter Horst L, Bulle EB, van Baarle FEHP and van de Poll MCG et al.. (2020) Anti-C5a antibody IFX-1 (vilobelimab) treatment versus best supportive care for patients with severe COVID-19 (PANAMO): an exploratory, open-label, phase 2 randomised controlled trial. Lancet Rheumatol 2: e764-e773 [PMID:33015643]

212. Waters SM, Brodbeck RM, Steflik J, Yu J, Baltazar C, Peck AE, Severance D, Zhang LY, Currie K and Chenard BL et al.. (2005) Molecular characterization of the gerbil C5a receptor and identification of a transmembrane domain $\mathrm{V}$ amino acid that is crucial for small molecule antagonist interaction. J Biol Chem 280: 40617-23 [PMID:16230349]

213. Watson RR, Collier RJ and Preedy VR. (2017) D PRECLINICAL STUDIES OF DAIRYMILK AND DAIRY COMPONENTSON HEALTH In Nutrients in Dairy and Their Implications for Health and Disease Academic Press: 490 [ISBN: 9780128097632]

214. Weiler H. (2008) Tracing the molecular pathogenesis of antiphospholipid syndrome. J Clin Invest 118: 3276-8 [PMID:18802489]

215. Wende E, Laudeley R, Bleich A, Bleich E, Wetsel RA, Glage S and Klos A. (2013) The complement anaphylatoxin $\mathrm{C} 3 a$ receptor $(\mathrm{C} 3 \mathrm{aR})$ contributes to the inflammatory response in 
dextran sulfate sodium (DSS)-induced colitis in mice. PLoS ONE 8: e62257 [PMID:23638016]

216. Wenderfer SE, Wang H, Ke B, Wetsel RA and Braun MC. (2009) C3a receptor deficiency accelerates the onset of renal injury in the MRL/lpr mouse. Mol Immunol 46: 1397-404 [PMID:19167760]

217. Wetsel RA. (1995) Expression of the complement C5a anaphylatoxin receptor (C5aR) on nonmyeloid cells. Immunol Lett 44: 183-7 [PMID:7797249]

218. Wilken HC, Götze O, Werfel T and Zwirner J. (1999) C3a(desArg) does not bind to and signal through the human C3a receptor. Immunol Lett 67: 141-5 [PMID:10232396]

219. Wong AK, Finch AM, Pierens GK, Craik DJ, Taylor SM and Fairlie DP. (1998) Small molecular probes for G-protein-coupled C5a receptors: conformationally constrained antagonists derived from the C terminus of the human plasma protein C5a. J Med Chem 41: 3417-25 [PMID:9719594]

220. Woodruff TM, Arumugam TV, Shiels IA, Reid RC, Fairlie DP and Taylor SM. (2003) A potent human C5a receptor antagonist protects against disease pathology in a rat model of inflammatory bowel disease. J Immunol 171: 5514-20 [PMID:14607958]

221. Woodruff TM, Costantini KJ, Crane JW, Atkin JD, Monk PN, Taylor SM and Noakes PG. (2008) The complement factor C5a contributes to pathology in a rat model of amyotrophic lateral sclerosis. J Immunol 181: 8727-34 [PMID:19050293]

222. Woodruff TM, Crane JW, Proctor LM, Buller KM, Shek AB, de Vos K, Pollitt S, Williams HM, Shiels IA and Monk PN et al.. (2006) Therapeutic activity of C5a receptor antagonists in a rat model of neurodegeneration. FASEB J 20: 1407-17 [PMID:16816116]

223. Woodruff TM, Pollitt S, Proctor LM, Stocks SZ, Manthey HD, Williams HM, Mahadevan IB, Shiels IA and Taylor SM. (2005) Increased potency of a novel complement factor 5a receptor antagonist in a rat model of inflammatory bowel disease. J Pharmacol Exp Ther 314: 811-7 [PMID:15879003]

224. Woodruff TM, Strachan AJ, Dryburgh N, Shiels IA, Reid RC, Fairlie DP and Taylor SM. (2002) Antiarthritic activity of an orally active C5a receptor antagonist against antigen-induced monarticular arthritis in the rat. Arthritis Rheum 46: 2476-85 [PMID:12355496]

225. Woodruff TM, Strachan AJ, Sanderson SD, Monk PN, Wong AK, Fairlie DP and Taylor SM. (2001) Species dependence for binding of small molecule agonist and antagonists to the C5a receptor on polymorphonuclear leukocytes. Inflammation 25: 171-7 [PMID:11403208]

226. Wright AJ, Higginbottom A, Philippe D, Upadhyay A, Bagby S, Read RC, Monk PN and Partridge LJ. (2007) Characterisation of receptor binding by the chemotaxis inhibitory protein of Staphylococcus aureus and the effects of the host immune response. Mol Immunol 44: 2507-17 [PMID:17258808]

227. Wu MC, Brennan FH, Lynch JP, Mantovani S, Phipps S, Wetsel RA, Ruitenberg MJ, Taylor SM and Woodruff TM. (2013) The receptor for complement component C3a mediates protection from intestinal ischemia-reperfusion injuries by inhibiting neutrophil mobilization. Proc Natl Acad Sci USA 110: 9439-44 [PMID:23696668]

228. Xiao H, Dairaghi DJ, Powers JP, Ertl LS, Baumgart T, Wang Y, Seitz LC, Penfold ME, Gan L and $\mathrm{Hu}$ P et al.. (2014) C5a receptor (CD88) blockade protects against MPO-ANCA GN. J Am Soc Nephrol 25: 225-31 [PMID:24179165]

229. Xu DZ, Zaets SB, Chen R, Lu Q, Rajan H, Yang X, Zhang J, Feketova E, Bogdan N and Deitch EA et al.. (2009) Elimination of C5aR prevents intestinal mucosal damage and attenuates neutrophil infiltration in local and remote organs. Shock 31: 493-9 [PMID:18791492]

230. Yamamoto T. (2000) Molecular mechanism of monocyte predominant infiltration in chronic inflammation: mediation by a novel monocyte chemotactic factor, S19 ribosomal protein dimer. Pathol Int 50: 863-71 [PMID:11107061]

231. Yoshikawa M. (2015) Bioactive peptides derived from natural proteins with respect to diversity of their receptors and physiological effects. Peptides 72: 208-25 [PMID:26297549]

232. Yu M, Zou W, Peachey NS, McIntyre TM and Liu J. (2012) A novel role of complement in retinal degeneration. Invest Ophthalmol Vis Sci 53: 7684-92 [PMID:23074214]

233. Yuan G, Wei J, Zhou J, Hu H, Tang Z and Zhang G. (2003) Expression of C5aR (CD88) of synoviocytes isolated from patients with rheumatoid arthritis and osteoarthritis. Chin Med J 116: 1408-12 [PMID:14527377]

234. Zaidi AK and Ali H. (2007) C3a receptors signaling in mast cells. Adv Exp Med Biol 598: 126-40 [PMID:17892209]

235. Zhang H, Qin G, Liang G, Li J, Barrington RA and Liu DX. (2007) C5aR-mediated myocardial ischemia/reperfusion injury. Biochem Biophys Res Commun 357: 446-52 [PMID:17416341]

236. Zhang T, Wu KY, Ma N, Wei LL, Garstka M, Zhou W and Li K. (2020) The C5a/C5aR2 axis promotes renal inflammation and tissue damage. JCI Insight 5 [PMID:32191644]

237. Zhang X, Schmudde I, Laumonnier Y, Pandey MK, Clark JR, König P, Gerard NP, Gerard C, Wills-Karp M and Köhl J. (2010) A critical role for C5L2 in the pathogenesis of experimental allergic asthma. J Immunol 185: 6741-52 [PMID:20974988]

238. Zheng YY, Xie X, Ma YT, Yang YN, Fu ZY, Li XM, Liu F, Yang SJ, Ma X and Chen BD. (2011) 
S323I polymorphism of the C5L2 gene was not identified in a Chinese population with familial combined hyperlipidemia or with type 2 diabetes. Genet Mol Res 10: 3256-66 [PMID:22194190]

239. Zheng YY, Xie X, Ma YT, Yang YN, Fu ZY, Li XM, Ma X, Chen BD and Liu F. (2012) Relationship between type 2 diabetes mellitus and a novel polymorphism C698T in C5L2 in the Chinese Han population. Endocrine 41: 296-301 [PMID:22180093]

240. Zheng YY, Xie X, Ma YT, Yang YN, Fu ZY, Li XM, Ma X, Chen BD and Liu F. (2011) Relationship between a novel polymorphism of the C5L2 gene and coronary artery disease. PLOS ONE 6: e20984 [PMID:21698200] 